Jpn. J. Pharm. Health Care Sci.
ノー

\title{
グリチルリチン注射剂市販品の物性および 成分含量の比較検討
}

\author{
古閑健二郎 ${ }^{* 1}$, 李 帥 ${ }^{1}$, 大栁賀津夫 ${ }^{1}$, 高田寛治 ${ }^{2}$ \\ 北陸大学薬学部臨床薬剂学 ${ }^{1}$, 京都薬科大学薬物動態学 ${ }^{2}$
}

\section{Comparative Study of Physicochemical Properties and Constituent Contents of Glycyrrhizin Injectable Solutions}

\author{
Kenjiro Koga ${ }^{* 1}$, Sui $\mathrm{Ri}^{1}$, Kazuo Ohyanagi ${ }^{1}$ and Kanji Takada \\ Department of Clinical Pharmaceutics, \\ Faculty of Pharmaceutical Sciences, Hokuriku University ${ }^{1}$ \\ Department of Pharmacokinetics, Kyoto Pharmaceutical University ${ }^{2}$ \\ $\left[\begin{array}{l}\text { Received December 27, } 2007 \\ \text { Accepted March 7, 2008 }\end{array}\right]$
}

We evaluated the quality of parenteral injections (22 products) containing monoammonium glycyrrhizinate, the main extract from the Glycyrrhizae radix. The $\mathrm{pH}$ and osmolarity ratio of each product were within the range stated in the package insert.

The glycyrrhizic acid, glycine, and L-cysteine concentrations in the injection products were $2.07-2.51 \mathrm{mg} / \mathrm{mL}, 16.0-21.4$ $\mathrm{mg} / \mathrm{mL}$, and $1.04-1.30 \mathrm{mg} / \mathrm{mL}$, respectively. The concentrations of glycyrrhetinic acid and glycyrrhetic acid-3-0glucuronide, impurities that cause pseudo-aldosteronism, were $0.173-2.24 \mathrm{~g} / \mathrm{mL}$ and $0.777-8.29 \mathrm{~g} / \mathrm{mL}$, respectively, showing that there was a wide variation in the concentrations of these 2 substances among the products. Further, the results of discriminant analysis on impurity proportions suggested that it is possible to distinguish bulk powders from each other based on impurity contents. In conclusion, it is important to determine the proportions of impurities in glycyrrhizic acid products and their bulk powders in order to assess their quality.

Key words — glycyrrhizin, glycine, L-cysteine, quality, generic

\section{緒言}

今日 , 甘草抽出成分であるグリチルリチン酸を含有す るグリチルリチン酸モノアンモニウム塩・日局グリシ ン・L-システイン塩酸塩配合剂(以下, グリチルリチン 注射剂と略す)は 17 社の製造元，23社の発売元から 41 品目が上市されている．1管中の容量は 5，10，20，40 および $100 \mathrm{~mL}$ と異なるが, 成分濃度はすべて先発品と 同じである . 医療用医薬品のグリチルリチン酸モノアン モニウム塩原末の純度あるいは精製度に関する資料はな いが, グリチルリチン酸の高速液体クロマトグラフィー

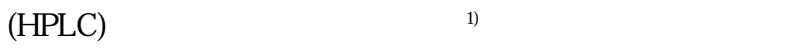
て存在が明らかであるグリチルレチン酸(グリチルリチ ン酸からグルクロン酸 2 分子が外れたもの)およびグリ
チルレチン酸モノグルクロニド体(グルクロン酸 1 分子 が外れたもの)の含有率 ${ }^{2}$ からグリチルリチン酸モノアン モニウム塩原末における純度は 80〜 90\% 程度であろう と推定される . このグリチルリチン酸モノアンモニウム 塩の純度に関して, 医薬部外品中のグリチルリチン酸塩 の定量が検討されている3) . 弚の純度は，高純度グリチ ルリチン酸塩の内標準法による HPLC 定量分析におい て $80 \%$ 弱であることが示された . また , 混在している 類縁化合物の HPLC 分析時における保持時間ならびに 化学構造式も示された ${ }^{3)}$. 本医薬品成分のグリチルリチ ン酸は構造式の18位炭素に結合する水素の位置がシス 型(18ß 型)のみをさす．しかし，光の光学異性体である トランス型(18 型)がわずかながら含有することもわ かっている4).

今回，入手できたグリチルリチン注射剂 22 製品を用 
いて, 物性值として pH および浸透圧比, 有効成分であ るグリチルリチン酸, グリシンおよびLーシステインの 濃度, グリチルリチン酸の主要加水分解産物であるグリ チルレチン酸およびグリチルレチン酸モノグルクロニド 体の濃度, ならびに化学構造式は不明であるがHPLC において検出されたピーク面積から捉えた不純物含有率 により市販品を比較検討した 。

\section{方法}

\section{1. 製品の入手}

2006 年 4 月に購入できたグリチルリチン注射剂を表 1 の左カラムの製造番号に, 再度，2006年 10 月に購入で きた同一品目の注射剂を右カラムの製造番号に示した . 17 社の製造元のうち 5 社の製品を購入できなかったこ とで，12社からの 22 製品を実験の対象とした . 全製品 の有効期限は 2008 年 1 月から 2009 年 5 月の範囲であっ た・ただし, 強力ネオミノファーゲンシーPおよびノ イファーゲン注は異なる製造番号の製品を購入できな かったことで, 各々 1製品のみとなった .

\section{2. 物性値の測定}

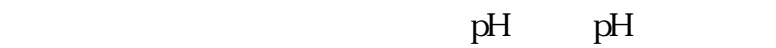
(SevenEasy，メトラー・トレド(株))を用いて測定した。 また，浸透圧比は各注射剂の浸透圧を浸透圧計(Semimicro Osmometer K-7400, Knauer GmbH)を用いて測定 し, 生理食塩水 $(0.9 \mathrm{w} / \mathrm{v} \% \mathrm{NaCl}$ 溶液)の浸透圧に対する 比として算出した .いずれの製品も3 回測定した .

\section{3. グリチルリチン酸濃度の測定}

各注射剂を $50 \mathrm{mM}$ リン酸塩緩衝液( $\mathrm{pH}$ 7.4)を用いて 200 倍に希釈し, HPLC 用分析試料とした。標準溶液は グリチルリチン標準品(和光純薬工業(株)，純度 99.8\%)
を $50 \%$ メタノールで溶解して $1 \mathrm{mg} / \mathrm{mL}$ とし，次に $50 \mathrm{mM}$ リン酸塩緩衝液( $\mathrm{pH}$ 7.4)を用いて $1 \mathrm{qu} \mathrm{g} / \mathrm{mL}$ に調製した。 HPLC の条件は, ODS カラム(CapcellPak C 18, MG タ イプ，内径 $4.6 \mathrm{~mm} \times$ 直径 $150 \mathrm{~mm}$, (株)資生堂)，カラム 温度 $40^{\circ} \mathrm{C}$, 測定波長 $254 \mathrm{~nm}$, 試料注入量 $59 \mathrm{~L}$, メ夕 ノール $/ 0.6 \%$ 過塩素酸水(55: 45)溶液を $25 \%$ アンモ二 ア水で $\mathrm{pH} 8$ に調整して移動相とし，流速 $0.8 \mathrm{~mL} / \mathrm{min}$ と した .いずれの製品も 3 回測定し, 兴の平均值と標準偏 差で示した。

\section{4. グリシン濃度の測定}

各注射剂を $200 \mathrm{mM}$ 水酸化ナトリウム溶液を用いて 2000 倍に希釈した . 標準溶液はグリシン(和光純薬工業 (株)，純度 $99.0 \%$ )を $200 \mathrm{mM}$ 水酸化ナトリウム溶液を用 いて $10 \mu \mathrm{g} / \mathrm{mL}$ に調製した . 希釈した試料溶液あるいは 標準溶液の $0.4 \mathrm{~mL}$ と $3 \%$ イソチオシアン酸フェニル-1プロパノール水溶液 $0.3 \mathrm{~mL}$ を混和し，50年，30分間の 条件で加温した．常温に戻した後，ベンゼン $0.1 \mathrm{~mL} を$ 正確に加えて $500 \mathrm{rpm}, 5$ 分間の条件で振盪(Vortex Shaker VR-36, タイテック(株))し,16,000 g, 15分間遠 心分離した . 上層液を除き，下層液 $200 \mu \mathrm{L}$ および $8 \mathrm{M}$ 塩酸 $200 \mu \mathrm{L}$ を混和し，水浴 $50^{\circ} \mathrm{C}$ で1 時間加温した . 常 温に戻した後, 酶酸エチル $400 \mu \mathrm{L} て ゙ 3$ 回抽出し, $70^{\circ} \mathrm{C}$ で蒸発乾固した . 残留物に移動相 $0.4 \mathrm{~mL}$ を正確に加え て溶解させ，HPLC 用の試料溶液とした .

HPLCの条件は, ODS カラム, カラム温度 $35^{\circ} \mathrm{C}$, 測 定波長 $254 \mathrm{~nm}$, 試料注入量 $50 \mu \mathrm{L}, 20 \mathrm{mM}$ 酢酸ナトリ ウム液/メタノール(80：20)を移動相とし，流速 $0.8 \mathrm{~mL} /$ min とした . いずれの製品も 3 回測定し，光の平均值と 標準偏差で示した。

5. ᄂーシステイン濃度の測定

各注射剂を開封後，ただちに $0.2 \mathrm{~mL}$ を量り， $2 \mathrm{M}$ 水

表 1 . 実験に用いたグリチルリチン注射剂

\begin{tabular}{|c|c|c|}
\hline 製品名 & \multicolumn{2}{|c|}{ 製造番号 } \\
\hline アスファーゲン注 & AS 2 L 05 G 1 & 6 C 3004 \\
\hline キョウミノチン & 12155 & 12165 \\
\hline 強力ネオミノファーゲンシーP $20 \mathrm{~mL}$ & P 0215 & - \\
\hline グリファーゲンC & $5 \mathrm{PL} 32$ & $6 \mathrm{PL} 04$ \\
\hline グリベルチン静注液 20 mL & 471911 & 503605 \\
\hline グルコリン S 注射液 & $60110 \mathrm{C}$ & $60503 C$ \\
\hline ケベラ S注 & 0015 LC & 0017 M 6 \\
\hline ニチファーゲン注 & 702062 & 126062 \\
\hline ネオファーゲン注 & M 6 A 74 & M 6 E 95 \\
\hline ノイファーゲン注 $20 \mathrm{~mL}$ & $01 \mathrm{DA}$ & - \\
\hline ヒシファーゲンC 注 & $06 \mathrm{~F} 01$ & $06 \mathrm{H} 08$ \\
\hline ミノフィット注 $20 \mathrm{~mL}$ シリンジ & 060307 A A & $060525 \mathrm{AA}$ \\
\hline
\end{tabular}


酸化ナトリウム溶液 $0.1 \mathrm{~mL}$ および $0.4 \%$ 塩化ベンジル エタノール溶液 $0.2 \mathrm{~mL}$ を加えよく混和した . 標準溶液 は L-システイン(和光純薬工業(株)，純度 $99.0 \%) を$ 精製 水を用いて $1 \mathrm{mg} / \mathrm{mL}$ に調製し，ただちに $2 \mathrm{M}$ 水酸化ナ トリウム溶液 $0.1 \mathrm{~mL}$ および $0.4 \%$ 塩化ベンジルエタ ノール溶液 $0.2 \mathrm{~mL}$ を混和した.調製した両試料を常温 で 30 分間放置した後, クロロホルム $0.1 \mathrm{~mL}$ を正確に添 加した $500 \mathrm{rpm}, 5$ 分間振盪し, 15 分間放置した後, $2,800 \mathrm{~g}, 15$ 分間遠心分離を行った . 上清層の $0.2 \mathrm{~mL}$ を HPLC 用試料溶液とした .

HPLC の条件は, ODS カラム, カラム温度 $40^{\circ} \mathrm{C}$, 測 定波長 $254 \mathrm{~nm}$, 試料注入量 $50 \mu \mathrm{L}, 20 \mathrm{mM}$ リン酸二水 素カリウム液/メタノール(55: 45)を移動相とし, 流速 $0.7 \mathrm{~mL} / \mathrm{min}$ とした . いずれの製品も 3 回測定し，炎の 平均値と標準偏差で示した。

\section{6. グリチルレチン酸濃度の測定}

各注射剂を $50 \mathrm{mM}$ リン酸塩緩衝液( $\mathrm{pH}$ 7.4)を用いて 2 倍に希釈し，HPLC 用分析試料とした．標準溶液はグリ チルレチン酸(和光純薬工業(株), 純度 100\%)を $50 \%$ 工 タノールで溶解して $0.2 \mathrm{mg} / \mathrm{mL}$ とし, 次に $50 \mathrm{mM}$ リン 酸塩緩衝液(pH 7.4)を用いて 2.qu g/mL に調製した。

HPLC の条件は, ODS カラム, カラム温度 $40^{\circ} \mathrm{C}$, 測 定波長 $254 \mathrm{~nm}$, 試料注入量 $50 \mu \mathrm{L}$, メタノール $/ 0.6 \%$ 過 塩素酸水(80: 20)溶液を $25 \%$ アンモニア水で pH 8 に調 整して移動相とし，流速 $1.0 \mathrm{~mL} / \mathrm{min}$ とした．いずれの 製品も 3 回測定し，谷の平均値と標準偏差で示した。

\section{7. グリチルレチン酸モノグルクロニド体濃度の測定}

各注射剂を $50 \mathrm{mM}$ リン酸塩緩衝液( $\mathrm{pH}$ 7.4)を用いて 2 倍に希釈し，HPLC 用分析試料とした．標準溶液はグリ チルレチン酸モノグルクロニド体(和光純薬工業(株)，純 度 $96.6 \%)$ を $50 \%$ メタールで溶解して $0.2 \mathrm{mg} / \mathrm{mL}$ と し , 次に $50 \mathrm{mM}$ リン酸塩緩衝液( $\mathrm{pH}$ 7.4)を用いて $2.0 \mu \mathrm{g} /$ $\mathrm{mL}$ に調製した .

HPLC の条件は, ODS カラム, カラム温度 $40^{\circ} \mathrm{C}$, 測 定波長 $251 \mathrm{~nm}$, 試料注入量 $50 \mu \mathrm{L}$, メタノール/0.6\% 過 塩素酸水(78: 22)溶液を $25 \%$ アンモニア水で $\mathrm{pH} 2.5$ に 調整して移動相とし，流速 $0.8 \mathrm{~mL} / \mathrm{min}$ とした．いずれ の製品も 3 回測定し, 弚の平均值と標準偏差で示した .

8. HPLC 分析のピークエリアから捉えた不純物比率の 算出

HPLC 測定において，不純物と思われるピークを検出 したグリチルリチン酸(図 $1 \mathrm{~A}$ ) およびグリチルレチン酸 モノグルクロニド体(図 1 B)の二種類について，不純物 のピーク面積の比率を算出した . グリチルリチン酸濃度 の HPLC 測定において，試料を注入後，12分までに検
出されたピークのなかで, 保持時間が 6 分付近および 8 分付近の二種のピークを不純物ピークとみなした．不純 物ピーク面積および 9 分付近のグリチルリチン酸のピー ク面積の和に対する不純物ピーク面積の比率を不純物比 率として算出した . グリチルレチン酸モノグルクロニド 体の HPLC 測定において, 試料を注入後, 保持時間が 5.7 分付近から 19 分付近までのピークのなかで 9.3 分付 近に検出されたグリチルレチン酸モノグルクロニド体の ピーク以外を未知不純物によるピークとみなした . 未知 不純物ピーク面積およびグリチルレチン酸モノグルクロ ニド体のピーク面積の和に対する未知不純物ピーク面積 の比率を不純物比率として算出した . いずれの製品にお いても各々の不純物ピークをほぼ同じ保持時間に観察で きたことで，ピーク面積の比率での評価は妥当であると 判断した.

\section{9. 統計処理}

測定値の統計処理は，一元配置分散分析後，群間の比 較はTukey 検定を用い, 危険率 5\% 未満を有意差あり と判定した

グリチルリチン酸モノアンモニウム塩原末を提供する メーカー名を把握できたグリチルリチン注射斉に対する 判別分析を行った . 原末メーカーであるアルプス薬品工 業株式会社，宏輝株式会社，常盤薬品工業株式会社およ び丸善製薬株式会社の4社を群とした．判別分析におけ る変量は, グリチルリチン酸濃度に対するグリチルレチ ン酸濃度あるいはグリチルレチン酸モノグルクロニド体 の比率 , ならびにグリチルリチン酸のピーク面積に対す る不純物ピーク面積あるいはグリチルレチン酸モノグル クロニド体のピーク面積に対する不純物ピーク面積の比 率とした . 判別の有意性はWilksのラムダ統計量を用 い, ラムダ統計量の分布が $F$ 分布に近似できると仮定 し，統計処理ソフトMulcel およびMicrosoft Excel 2003 を用いて解析した。

結果

1. $\mathrm{pH}$ 值と浸透圧比

グリチルリチン注射剂の $\mathrm{pH}$ 值および浸透圧比を表 2 に示す．いずれのグリチルリチン注射剂も添付文書に記 載された範囲内の值を示した。

\section{2. グリチルリチン酸濃度}

グリチルリチン注射剂中のグリチルリチン酸濃度を図 2 に示す.グリチルリチン酸濃度は $2.07 〜 2.51 \mathrm{mg} / \mathrm{mL}$ の範囲にあった . Tukey の検定において , 先発品である 強力ネオミノファーゲンシーP $20 \mathrm{~mL}$ と対比して, 製品 ○のみ危険率 $5 \%$ 末満の有意差を認めた . 
A

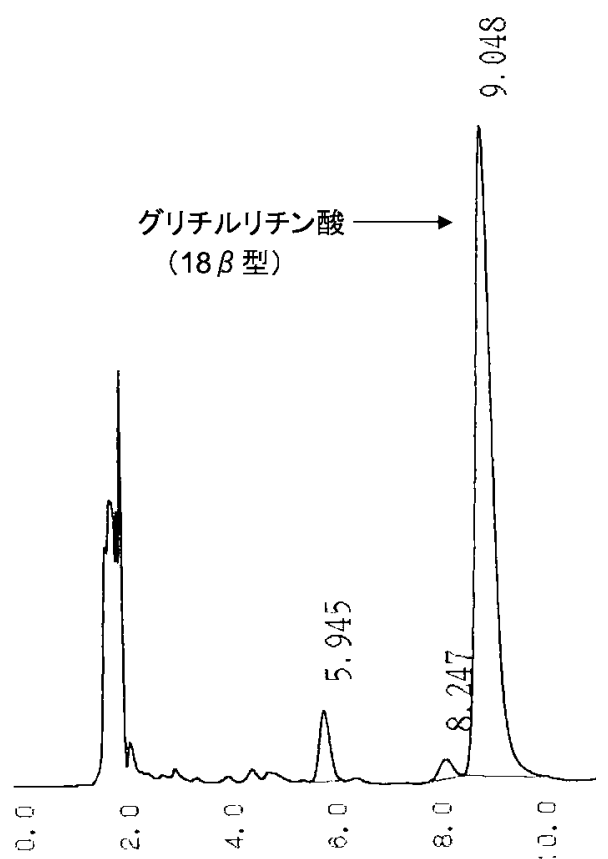

B

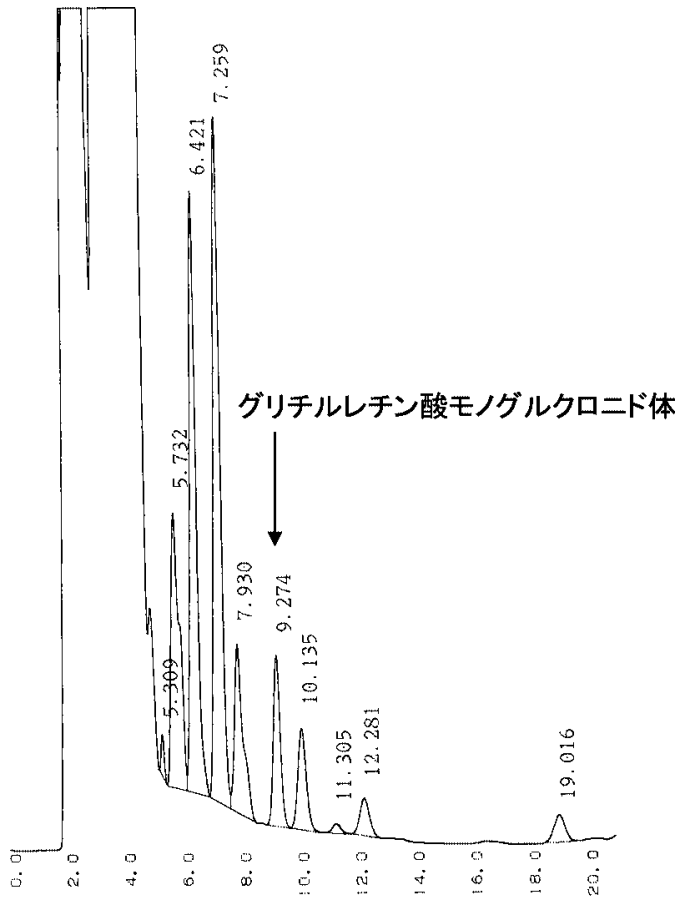

図 1.グリチルリチン注射剂市販品の HPLC 分析におけるグリチルリチン酸(A)およびグ リチルレチン酸モノグルクロニド体(B)のチャート

$A$; 約 6 分付近に出現したピークの成分は 24-ヒドロキシグリチルリチン酸, 8 分付 近の成分は有効成分であるグリチルリチン酸(18ß 型)の光学異性体 18a 型である . B；9.3 分付近に出現したグリチルレチン酸モノグルクロニド体以外のピーク成分に ついては不明である .

表 2. 各グリチルリチン注射斉の $\mathrm{pH}$ 值と浸透圧比

\begin{tabular}{|c|c|c|c|c|}
\hline \multirow[t]{2}{*}{ 製品 } & \multicolumn{2}{|r|}{$\mathrm{pH}$ 值 } & \multicolumn{2}{|r|}{ 浸透压比 } \\
\hline & 测定做 & （添付文書䛉杪佔） & 测定佔 & (添付文書記城估) \\
\hline A & 6.34 & $(6.0-7.0)$ & 1.56 & $(1.5-1.7)$ \\
\hline B & 6.80 & $(6.5-7.5)$ & 1.64 & $(1.5-1.8)$ \\
\hline C & 6.86 & $(6.0-7.5)$ & 1.92 & $(1.8-2.2)$ \\
\hline D & 6.86 & $(6.0-7.5)$ & 1.97 & $(1.8-2.2)$ \\
\hline $\mathrm{E}$ & 7.26 & (約 7.3) & 0.95 & (約 1) \\
\hline $\mathrm{F}$ & 7.28 & (約 7.3) & 1.01 & (約 1) \\
\hline G & 6.82 & $(6.7-7.4)$ & 0.98 & $(0.9-1.3)$ \\
\hline $\mathrm{H}$ & 6.82 & $(6.7-7.4)$ & 1.04 & $(0.9-1.3)$ \\
\hline I & 6.48 & $(6.0-7.4)$ & 1.00 & (約 1) \\
\hline $\mathrm{J}$ & 6.49 & $(6.0-7.4)$ & 1.08 & （約 1) \\
\hline K & 6.83 & $(6.0-8.5)$ & 0.98 & (約 1) \\
\hline $\mathrm{L}$ & 6.85 & $(6.0-8.5)$ & 1.05 & (約 1) \\
\hline M & 6.76 & $(6.5-7.5)$ & 1.91 & $(1.9-2.3)$ \\
\hline$N$ & 6.78 & $(6.5-7.5)$ & 1.95 & $(1.9-2.3)$ \\
\hline O & 6.60 & $(6.0-7.4)$ & 1.10 & $(0.9-1.2)$ \\
\hline $\mathrm{P}$ & 6.61 & $(6.0-7.4)$ & 1.06 & $(0.9-1.2)$ \\
\hline Q & 6.54 & $(5.5-7.5)$ & 2.04 & $(1.5-2.4)$ \\
\hline $\mathrm{R}$ & 6.54 & $(5.5-7.5)$ & 2.00 & $(1.5-2.4)$ \\
\hline $\mathrm{s}$ & 7.08 & $(6.0-8.0)$ & 1.04 & $(0.9-1.1)$ \\
\hline $\mathrm{T}$ & 7.07 & $(6.0-8.0)$ & 0.98 & $(0.9-1.1)$ \\
\hline U & 6.51 & $(6.0-7.4)$ & 1.00 & (約 1) \\
\hline $\mathrm{V}$ & 6.52 & $(6.0-7.4)$ & 1.07 & (約 1) \\
\hline
\end{tabular}

闹じ製品名称でも製造番号が異なるもの㤋分けて䒾示した。 表 1 の製品名の順序上は異なる。亳駼回数は 3 回とし，その平 均俏で示した。

变動保数が $2 \%$ 以付であったことで㮐淮偏差值は示していない。

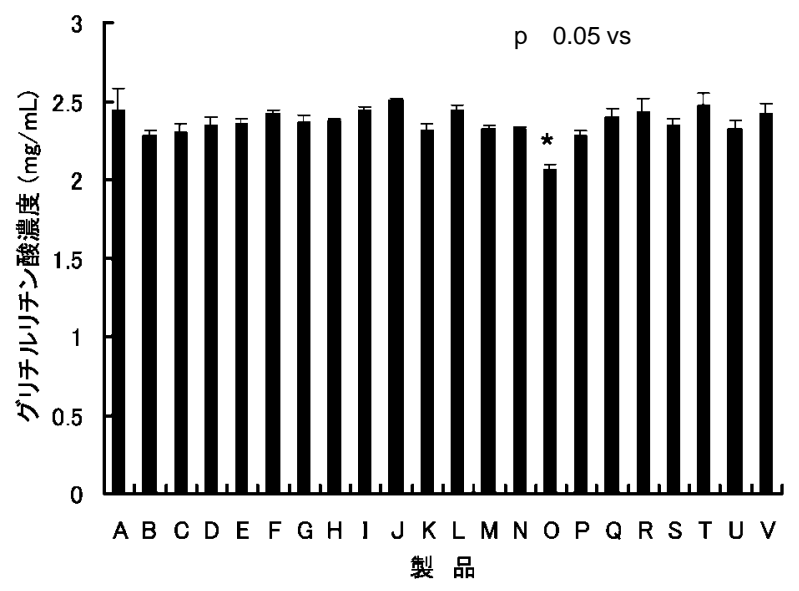

図 2. グリチルリチン注射剂市販品中におけるグリ チルリチン酸濃度

同じ製品名称でも製造番号が異なるものは分 けて表示した . 各データは平均値士 標準偏差 (3回分析)で示した. Tukey 検定の結果, 先発 品である強力ネオミノファーゲンシーP 20 $\mathrm{mL}$ と対比して製品 $\mathrm{O}$ のみ $\mathrm{P}<0.05$ であった .

3. グリシン濃度および L-システイン濃度

グリチルリチン注射斉中のグリシンおよびし-システ インの濃度を図 3 に示す . グリシンおよびし-システイ ン濃度は光れ光れ 16.0〜 $21.4 \mathrm{mg} / \mathrm{mL}$ および 1.04〜1.30 
$\mathrm{mg} / \mathrm{mL}$ の範囲にあり，14製品のグリシン濃度は添付文 書に記載された値，すなわち $20 \pm 1 \mathrm{mg} / \mathrm{mL}$ (添付文書記 載值の $\pm 5 \%)$ の範囲外であった. 先発品と比較したと き, グリシン濃度では 6 製品において , L-システイン 濃度においては 18 製品において統計学的な有意差が認 められた $(P<0.05)$.

4. グリチルレチン酸およびグリチルレチン酸モノグル クロニド体濃度

不純物として化学構造が明確にされているグリチルレ チン酸およびグリチルレチン酸モノグルクロニド体の製 品中に含有される濃度を図 4 に示す . 製品中のグリチル レチン酸濃度の最低值および最大值は 0.173 $0.001 \mu \mathrm{g} /$ $\mathrm{mL}$ および $2.24 \pm 0.23 \mathrm{~g} / \mathrm{mL}$ であり，光の差は 13 倍に も上がった . 一方, 製品中のグリチルレチン酸モノグル クロニド体濃度の最低值および最大值は $0.777 \pm 0.015$

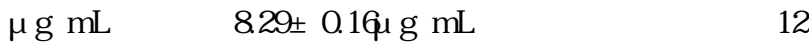
倍を示した . 先発品と比較したとき,グリチルレチン酸 濃度では 12 製品において, グリチルレチン酸モノグル クロニド体濃度では 18製品において，統計学的に有意 差が生じた $(P<0.05)$.

\section{5. 不純物のピークエリア}

グリチルリチン酸測定時における不純物比率は, 最小

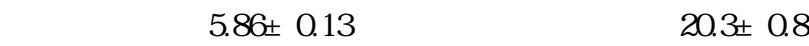
\%であった . 一方, グリチルレチン酸モノグルクロニド 体測定時における不純物比率は，最小値の製品では 56.4 $\pm 0.8 \%$, 最大值の製品では $97.2 \pm 0.2 \%$ であった .

\section{6. 判別分析}

グリチルリチン酸濃度に対するグリチルレチン酸ある いはグリチルレチン酸モノグルクロニド体の濃度の比率 を変量として判別統計処理を行ったところ，分散共分散 行列の等分散性の検定では，X² 值は $21.9, \mathrm{P}$ 值は 0.00932 となった . この結果は 4 群の分散共分散行列が 異なることを反映する．また，判別の有意性の検定では $\mathrm{P}$ 值 $=0.00355$ となり，1\% 未満で有意差ありとなった . グリチルリチン酸のピーク面積に対する不純物ピーク 面積あるいはグリチルレチン酸モノグルクロニド体の ピーク面積に対する不純物ピーク面積の比率を変量とし て判別統計処理を行ったところ, 分散共分散行列の等分 散性の検定では，X² 值 $=24.5, P$ 値 $=0.00355$ となった . また，判別の有意性の検定では $\mathrm{P}$ 値 $=0.000011$ となり， $0.1 \%$ 未満で有意差ありと判定された .

\section{考察}

添付文書に記載されている組成・性状には，成分，添 加物, 性状, $\mathrm{pH}$, 浸透圧比の各項目が記載されている. 成分はすべてのグリチルリチン注射剂において同じ濃度 であるが , 添加物には酸化防止剂として日局亜硫酸ナト リウム, 亜硫酸水素ナトリウム, ピロ亜硫酸ナトリウム 等が使用され，製造メーカーごとに相違が認められる． $\mathrm{pH}$ 調整剂として日局アンモニア水が主として使用され ているが，ただ単に $\mathrm{pH}$ 調整剤と記載してある場合もあ る. 弚の他の添加物として, 目的は浸透圧調整, 溶解液 等と推察されるが, 日局塩化ナトリウム, 生理食塩水,
A

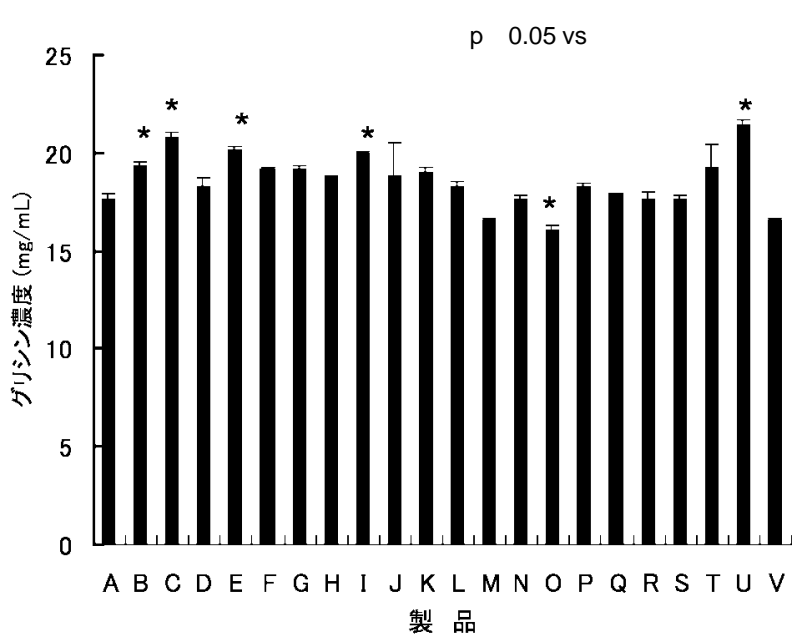

B

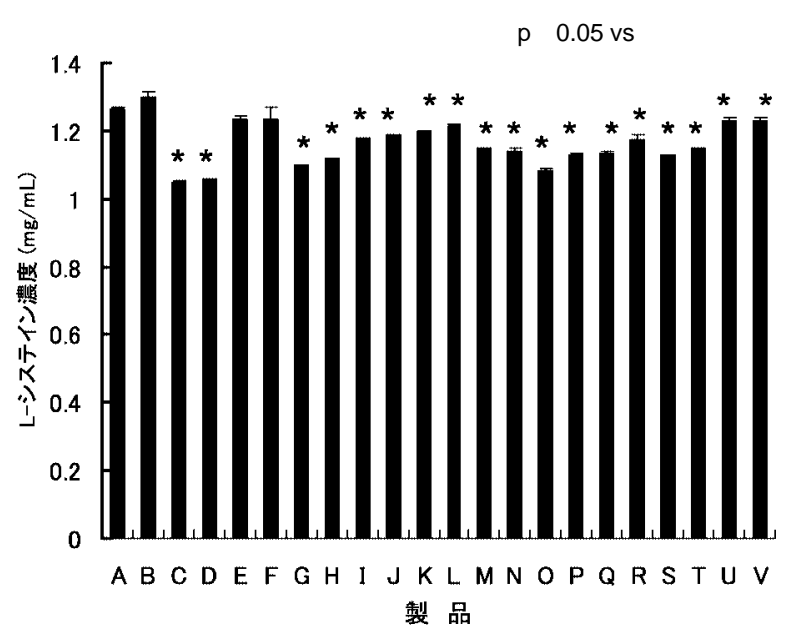

図 3.グリチルリチン注射剂市販品におけるグリシン $(\mathrm{A})$ および L-システイン $(\mathrm{B})$ 濃度 同じ製品名称でも製造番号が異なるものは分けて表示した . 各データは平均値 \pm 標準偏差(3回分析)で示した.Tukey 検定の結果, 先発品である強力ネオミノ ファーゲンシーP $20 \mathrm{~mL}$ と対比して, グリシン濃度では 6 製品が, L-システイ ン濃度では 18 製品が $\mathrm{P}<0.05$ であった . 
A

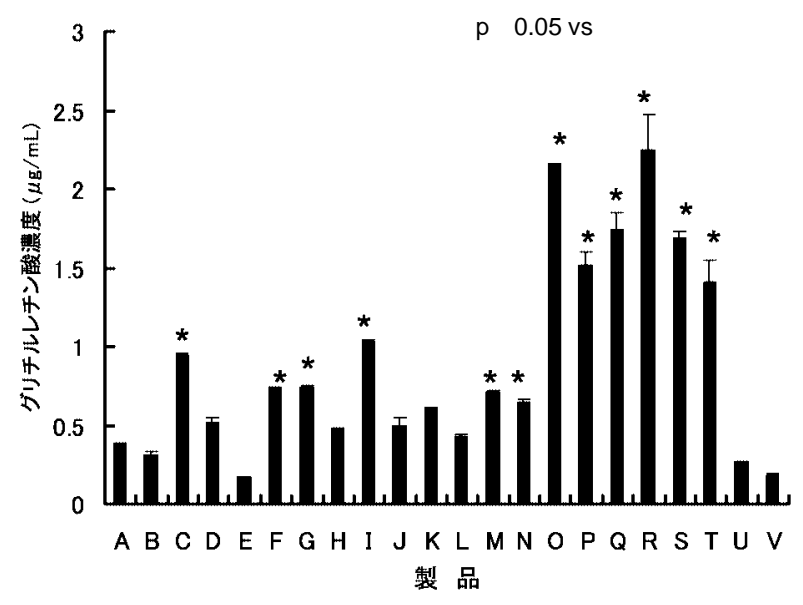

B

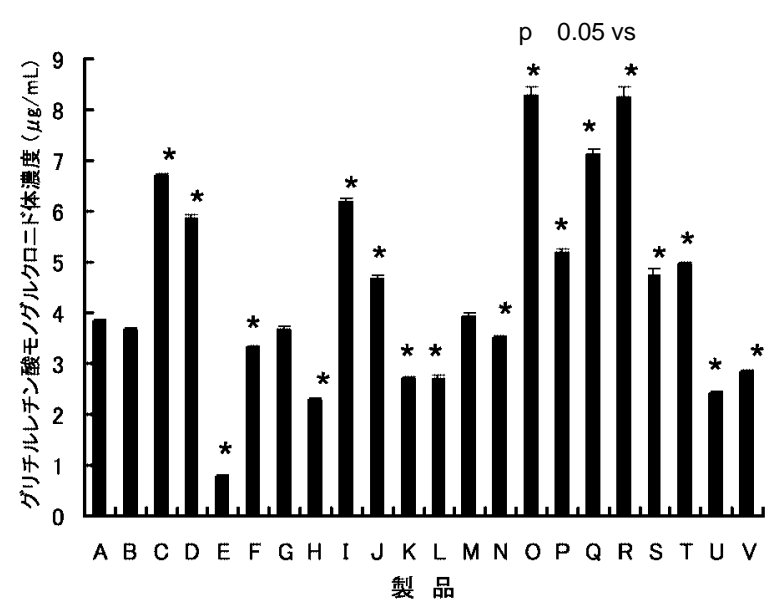

図 4 . グリチルリチン注射剂市販品におけるグリチルレチン酸(A)およびグリチルレ チン酸モノグルクロニド体(B)濃度

同じ製品名称でも製造番号が異なるものは分けて表示した . 各データは平均值 \pm 標準偏差(3 回分析)で示した . Tukey 検定の結果, 先発品である強力ネオミノ ファーゲンシーP $20 \mathrm{~mL}$ と対比して, グリシン濃度では 12 製品が , L-システ イン濃度では 18 製品が $\mathrm{P}<0.05$ であった 。

D-ソルビトール, クエン酸, 炭酸水素ナトリウム , 水 酸化ナトリウム , ブドウ糖などが使用されている . 添加 物の違いにより $\mathrm{pH}$ 值および浸透圧比は異なるが，これ ら注射㓢が主に点滴に混注することで使用されることか ら，医薬品としての治療効果に影響を及ぼす要因には該 当しないと考えられる．不純物を含めた成分の安定性に おいて，有効成分の安定性は市販のメーカーが有効期限 内において保証していること, 本研究において指摘する 不純物に関して明記された安定性の報告例を見つけるこ とができなかったが，製造メーカーの担当者の意見とし て, グリチルレチン酸は広範囲の $\mathrm{pH}$ 領域の水溶液中で 安定であること, また, グリチルレチン酸モノグルクロ ニド体は強酸でない限りグルクロン酸分子が外れること がないことから，添付文書の $\mathrm{pH}$ 值に示された範囲(最小 值 pH 5.5 ，最大值 pH 8.5)では，不純物を含めた成分の 安定性および存在比が変動することはないと思われる．

有効成分であるグリチルリチン酸,グリシンおよびL-

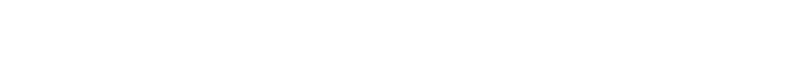
き, 先発品に対して統計学的有意差を認める後発品を確 認した。しかしながら，この統計学的解析結果は，1製 品あたりの測定值の変動(標準偏差値)が非常に小さかっ た .すなわち，実測值の分散が小さくなったことでわず かの平均値の差から有意差が生じたと推察する. 以前, グリチルリチン注射剂において, 先発品と後発品との間 で治療効果に差があることが報告され占，グリチルリチ ン酸の成分含量の相違が指摘された．关の後，このグリ チルリチン酸含量の違いはおおむね解決されたと考え,
22 製品の成分含量の平均値と標準偏差値より，95\% 信 頼区間内に全製品が分布するかどうかについて調べた . 兴の結果, グリシン濃度の平均值と光の標準偏差は 18.6 $\mathrm{mg} / \mathrm{mL}$ および $1.4 \mathrm{mg} / \mathrm{mL}, \mathrm{L}$-システイン濃度の平均值

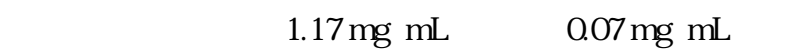
り，95\% 信頼区間内に全製品が包含された .グリチル リチン酸濃度の平均値および標準偏差は $2.36 \mathrm{mg} / \mathrm{mL}$ お よび $0.09 \mathrm{mg} / \mathrm{mL}$ であり，製品 0 のみ $95 \%$ 信頼区間か ら外れた . 以上のことから，3成分の濃度とも先発品と の比較では統計学的に $5 \%$ 未満の有意差を認めたもの の，顕著な相違があるとは考えられない .

グリシン含量が添付文書記載値 $(20 \mathrm{mg} / \mathrm{mL})$ に達して いない製品が数多く検出された要因として , 分析法の相 違が考えられる . 日局グリシンの定量法である電位差滴 定法が通常用いられるが, 今回, HPLC 法を用いたこと により，乥の測定値を低く見積もった可能性を否定でき ない。

商品名を表示していないことから，図 2および図 $3 に$ おいては, 同一製品名で製造番号が異なる製品間の比較 はできないが, 成分濃度の違いに顕著な差はなく, 品質 管理が行き届いていたと考えられる。

グリチルリチン酸の主要加水分解産物として, グリチ ルレチン酸およびグリチルレチン酸モノグルクロニド体 が存在する .グリチルレチン酸はグリチルリチン酸と同 樣に，副腎皮質の電解質あるいは糖質コルチコイド樣作 用6) , 抗炎症作用 ${ }^{78}$, 肝細胞の酸化ストレス障害抑制作 用ツなどを有している。一方で, 本注射剂の安全性上の 
問題となっている偽アルドステロン症については，これ までその原因物質がグリチルレチン酸とする報告 ${ }^{10}$ 11) グリチルレチン酸モノグルクロニド体とする報告 ${ }^{12}{ }^{131}$ が あり，明確に一種の物質であると断定できない．しか し，これら両薬物のどちらかあるいは両者ともに偽アル ドステロン症に関係している可能性が非常に高いことか ら，製斉中に含まれる両薬物の含量には注意を必要とす る . グリチルリチン酸の添付文書記載の用法・用量欄に は「慢性肝疾患に対しては 1日 1回 40〜 60 mL を静脈内 に注射または点滴静注する。年齢, 症状により適宜増減 する.なお，増量する場合は 1 日 $100 \mathrm{~mL}$ を限度とする」 と記されており，製剂中グリチルレチン酸およびグリチ ルレチン酸モノグルクロニド体濃度が最も高い製剂での

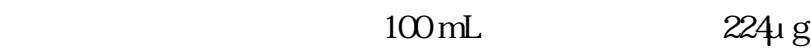

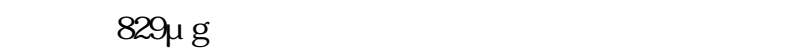
慢性肝疾患患者は週に2,3回の本製剂の投与を受けてい る．ここで，長期間にわたりグリチルリチン注射剂が投 与された後, 兴のグリチルリチン酸が体内でグリチルレ チン酸およびグリチルレチン酸モノグルクロニド体に代 謝され，偽アルドステロン症か惹起されるとき，グリチ ルレチン酸およびグリチルレチン酸モノグルクロニド体 が, どの程度体内に存在することでこの副作用が発現す るかが重要な問題である．この点に関して，興味深い報 告がある . ヒトにおけるグリチルリチン酸の経口投与に よる副作用検討において，血漿中カリウム濃度などの臨 床值より算出された無毒性レベルから，副作用の発現す る血漿中グリチルレチン酸濃度は $800 \mathrm{ng} / \mathrm{mL}$ 以上であ ることが報告された ${ }^{14)}$. また , グリチルレチン酸モノグ ルクロニド体(30, $100 \mathrm{mg} / \mathrm{kg})$ を 5 日間連続でモルモッ トの静脈内に投与したとき，100 mg/kg の投与群のみ偽 アルドステロン発症の指標の一つである血漿中カリウム 值が有意に低下した報告 ${ }^{13)}$ があるが，この実験における 血液中グリチルレチン酸モノグルクロニド体濃度は測定 されていなかったことで, 血液中あるいは組織中におけ るグリチルレチン酸モノグルクロニド体濃度がどのレベ ルで偽アルドステロン症を引き起こすかという議論はで きない．しかしながら，この著者ら ${ }^{131}$ はグリチルリチン 製剂を長期間投与することで, グリチルレチン酸モノグ ルクロニド体の蓄積量が徐々に増え, 最終的に偽アルド ステロン症を惹起しているだろうと結論している．した がって，一般に薬物を排泄する力が衰えた高齢者やこれ らの薬物に対する感受性の高い患者においては, 低カリ ウム血症などの副作用発現頻度を抑えるためにも，投与 量あるいは投与間隔の設定が重要な事項と位置づけられ よう.

製品中に不純物として含まれる両薬物の含量が，偽ア ルドステロン症の発現率を高めるかどうかは最も関心が 持たれるであろう．これに対する解決の系口となる報告
がある．まず，グリチルリチン注射斉 $(40 \mathrm{~mL}) を$ 健常ヒ 卜被験者の静脈内に投与したとき, グリチルレチン酸は 投与後約 6 時間くらいから血中に出現し，24 時間後に ピーク(約 $100 \mathrm{ng} / \mathrm{mL})$ を示したこと，ならびに慢性肝疾 患患者に同量を静脈内に投与したとき，グリチルレチン 酸は投与約 10 時間後に検出された ${ }^{15)}$.この報告は，わ れわれの疑問に対して, グリチルリチン酸の代謝に伴い 生じたグリチルレチン酸が血中濃度に反映していること を裏付けている.しかし, 兴の一方で, グリチルリチン 注射斉 $(40 \mathrm{~mL})$ を慢性肝疾患患者の静脈内に 30 分かけて 持続的に投与した臨床試験において , 血中グリチルレチ ン酸濃度が投与開始 30 分後に $89.9 \pm 5.5 \mathrm{ng} / \mathrm{mL} ， 6$ 時間

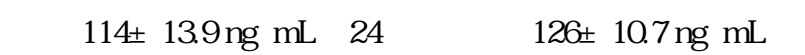
あった報告 ${ }^{16)}$ から考えると，注入終了時にただちにはグ リチルレチン酸が血中に検出されないという矢野らの報 告 ${ }^{15)}$ と矛盾する .この注入終了時にグリチルレチン酸が 検出された結果に対して，注射剂中に不純物として含有 されていた量が血液中に存在し，測定に反映した可能性 がある. 投与開始後 6 時間から 24 時間まで，血中グリ チルレチン酸濃度が低下しなかった要因として , 不純物 として体内に投与されたグリチルレチン酸の消失過程と グリチルリチン酸の代謝に伴うグリチルレチン酸が増大 してきた過程が複合されたことで, みかけ上, 血中のグ リチルレチン酸濃度がほぼ一定值を保持した可能性が考 えられる . 上述した二つの臨床報告における被験者が異 なるため, 単純に血中グリチルレチン酸濃度を比較する ことはできないが , 24 時間での血中グリチルレチン酸 濃度が後者の報告において 2 割程度高い原因として，製 品中に含有されていたグリチルレチン酸による影響のあ る可能性も否定できない，ただし，ヒトにおける偽アル ドステロン症として低カリウム血症などの副作用を惹起 するグリチルレチン酸の血中レベルが $800 \mathrm{ng} / \mathrm{mL}$ 以上 であるとする報告 ${ }^{14}$ から捉えた場合，注射剂中に含有さ れるグリチルレチン酸単独での血中動態の把握が必要に なる . ラットにおけるグリチルレチン酸の静脈内投与後

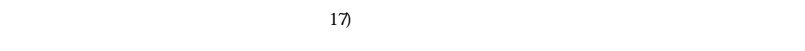
たグリチルリチン注射剂 $100 \mathrm{~mL}$ 中に含まれるグリチル レチン酸の最大含有量 $224 \mathrm{~g}$ gをてはめたとき，投与 後 12 時間での血漿中グリチルレチン酸濃度は $14 \mathrm{ng} / \mathrm{mL}$ と算出された . このレベルは副作用を惹起するレベル $800 \mathrm{ng} / \mathrm{mL}$ からみて十分に低く, 混在している不純物単 独での副作用発現の可能性はないであろう．しかしなが ら，グリチルリチン注射剂の反復投与が長期間にわたつ て継続される場合，特に投与量が多い処方の場合では， 製剂中に含有される不純物がグリチルリチン酸の代謝に より生じた成分により惹起されるであろう偽アルドステ ロン発症の時期を早めたり，副作用の程度に影響を及ぼ す可能性も考えられる。 
製剂ごとに比較した不純物比率の検討において，グリ チルリチン酸のHPLC チャートに出現した約 6 分付近 の成分は24-ヒドロキシグリチルリチン酸 ${ }^{3)}, 8$ 分付近の 成分はグリチルリチン酸(18及 型)の光学異性体 18 型4) であることが報告されている．両成分がグリチルリチン 酸の治療にどのような影響を及ぼすかについての報告は 見あたらないが，光の含有比率が最大で約 20\%を示し たことから品質管理において注意を払う必要があろう． グリチルレチン酸モノグルクロニド体の HPLC チャー 卜上に出現したピークについて，弚れらの成分について はなんら報告がなかった . 非常に高い不純物の比率を示 したことで, グリチルリチン酸モノアンモニウム塩の原 末中に含まれる種々の成分がグリチルレチン酸モノグル クロニド体含量よりも多く含まれている可能性がある .

判別分析の結果, グリチルリチン酸濃度に対するグリ チルレチン酸あるいはグリチルレチン酸モノグルクロニ ド体の濃度の比率を変量とした場合も, グリチルリチン 酸のピーク面積に対する不純物ピーク面積あるいはグリ チルレチン酸モノグルクロニド体のピーク面積に対する 不純物ピーク面積の比率を変量とした場合も，危険率 1 \%未満で有意差ありと判定されたことは, グリチルリチ ン酸モノアンモニウム塩の原末の種類によって製品の品 質が影響を受けたことを反映する．また，逆に製品の不 純物含量をもとに原末の種類あるいは品質を判別できる ことを意味する．

以上の検討より，生薬抽出成分であるグリチルリチン 酸を含有するグリチルリチン注射剂が, 慢性肝疾患患者 に対して長期にわたり静脈内に投与されることから，原 末における不純物含有率は品質管理の 1項目として測定 されることか望まれる .

\section{引用文献}

1) 福島悦子, 矢崎廣久, 久門勝利, 高速液体クロマ卜 グラフィーによる甘草含有製剤中のグリチルリチン 酸の定量 , 千葉衛研報告 , 18, 39-42 (1994).

2) 名德倫明, 今井康陽, 福田和人, 中西晶子, 塩石知 子, 乾とし子, 宮本絵美, 未村奈津子, 小来田幸代， 澤井良之, 黑川正典 , 川口進一, グリチルリチン注 射剂「ミノフィット」(プレフィルドシリンジ製剂) の有用性について, 医療薬学，33, 463-468 (2007).

3) 林正人, 門脇英二, 高松翼, 松岡昌弘, 高速液体力 ロマトグラフィーによる医薬部外品中のグリチルリ チン酸塩の定量における異常挙動の解明, 薬学杂隹 誌, 112, 496-502 (1992).

4) K. Koga, K. Ohmachi, S. Kawashima, K. Takada, M. Murakami, Determination of 18 -glycyrrhizin and 18 $\beta$-glycyrrhizin in dog plasma by high-performance liquid chromatography, J. Chromatogr. B ., 738, 165-168 (2000).
5) 古庄憲浩, 中嶋寿, 有山嚴, 久保德彦, 柏木謙一郎, 鍋島茂樹，柏木征三郎，林純，C 型慢性肝炎に対す る静注グリチルリチン治療における強力ネオミノフ アーゲンC $(\mathrm{SNMC})$ と光の後発品投与による効果の 比較, 臨床と治療, 80, 179-184 (2003).

6) L.H. Louis, J.W. Conn, Preparation of glycyrrhizinic acid, the electrolyte active principle of licorice: its effects upon metabolism and upon pituitary-adrenal function in man, J. Lab. Clin. Med ., 47, 20-28 (1956).

7) R.S. Finney, G.F. Somers, The antiinflammatory activity of glycyrrhetinic acid and derivatives, J. Pharm. Pharmacol ., 10, 613-620 (1958).

8) K.K. Tangri, P.K. Seth, S.S. Parmar, K.P. Bhargava, Biochemical study of anti-inflammatory and antiarthritic properties of glycyrrhetic acid, Biochem. Pharmacol., 14, 1277-1281 (1965).

9) E. Gumpricht, R. Dahl, M.W. Devereaux, R.J. Sokol, Licorice compounds glycyrrhizin and $18 \beta$-glycyrrhetinic acid are potent modulators of bile acid-induced cytotoxicity in rat hepatocytes, J. Biol. Chem., 280, 10556-10563 (2005).

10) J.W. Conn, D.R. Rovner, E.L. Cohen, Licorice induced pseudoaldosteronism. hypertension, hypokalemia, aldosteronopenia, and suppressed plasma renin activity, JAMA., 205, 492-496 (1968).

11) P.M. Stewart, A.M. Wallace, R. Valentino, D. Burt, C. H.L. Shackleton, C.R.W. Edwards, Mineralocorticoid activity of liquorice: 11-beta hydroxysteroid dehydrogenase deficiency comes of age, Lancet, 2, 821-824 (1987).

12) H. Kato, M. Kanaoka, S. Y ano, M. Kobayashi, 3-Monoglucuronyl- glycyrrhetinic acid is a major metabolite that causes licorice induced pseudoaldosteronism, $J$. Clin. Endocrinol. Metabol ., 80, 1929-1933 (1995).

13) N. Ohtake, A. Kido, K. Kubota, N. Tsuchiya, T. Morita, Y. Kase, S. Takeda, A possible involvement of 3 monoglucuronyl-glycyrrhetinic acid, a metabolite of glycy rrhizin (GL), in GL-induced pseudoaldosteronism, Life Sci., 80, 1545-1552 (2007).

14) C.E. van Gelderen, J.A. Bijlsma, W. van Dokkum, T.J. Savelkoul, Glycyrrhizic acid : the assessment of a no effect level, Human Exp. Toxicol., 19, 434-439 (2000)

15) 矢野三郎, 中野直子, カンゾウ(甘草), 治療学, 7, 703-708 (1981).

16) 高橋美香子, 中野哲, 武田功, 熊田卓, 杉山恵一, 長田敏正, 桐山勢生, 豊田秀徳, 島田真, 佐守友実, C 型慢性肝炎および肝硬変に対するグリチルリチン 製斉投与時のグリチルリチンおよびグリチルレチン 酸の血中動態について, 日本消化器病学会雑誌, 92, 1929-1936 (1995).

17) T.H. Tsai, C.F. Chen, High-performance liquid chroma tographic determination of 18 -glycyrrhetinic acid and $18 \beta$-glycyrrhetinic acid in rat plasma: application to pharmacokinetic study, J. Chromatogr., 567, 405-414 (1991). 